\title{
HUBUNGAN KOIMPETENSI LEADERSHIP GURU PAI DENGAN MOTIVASI BELAJAR SISWA KELAS XI DI MADRASAH ALIYAH DARUL MUTTAQIEN DALAM PEMBELAJARAN JARAK JAUH
}

\author{
Raihan Nur Azizah ${ }^{1}$, Sri Nurul Milla ${ }^{2}$, Syarifah Gustiawati ${ }^{3}$ \\ Universitas Ibn Khaldun Bogor
}

\begin{abstract}
The Covid-19 pandemic has helped change the world of education from learning, methods and targets. Currently, one of the solutions to keep Teaching and Learning activities and lectures going is to carry out full distance learning and take advantage of online education platforms. Besides that, can also implement a seminetwork distance learning system, where task are sent via message applications and there is no direct interaction. This research aims to determine the leadership competence of teacher of Islamis Religious Education in senior high school of Darul Muttaqien, the learning motivation students of class XI senior high school in Darul Muttaqien and to find out whether there is a correlation between leadership competence of teacher of Islamic Religious Education and student learning motivation at class XI senior high school in Darul Muttaqien. The approach in this research uses a quantitative approach with a correlational method carried out at Darul Muttaqien Senior High School in class $X I$. The result showed that there was a positive correlation between the two variables. Based on the results of the correlation test with the pearson correlation formula with a significant level of 5\%, it is known that the correlation value between the leadership competence of Islamic Religious Education teachers and the learning motivation of grade XI student at Senior High School Darul Muttaqien is 0,895. When viewed from the interpretation table the value obtained is 0,895 which lies between the interval 0,70-0, 90 that there is a relationship between the leadership competence of Islamic Religious Education teachers and student learning motivation in distance learning in class XI of Senior High School Darul muttaqien, and this correlation strong.
\end{abstract}

Keywords: competence leadership, motivation to learn, distance learning

\section{PENDAHULUAN}

Pandemi COVID 19 turut mengubah dunia pendidikan, mulai dari metode pembelajaran, penganggaran, hingga sasarannya. Metamoforsis ini membutuhkan adaptasi agar kegiatan belajar-mengajar berjalan efektif. Pandemi COVID 19 di Indonesia telah membuat sistem pembelajaran berubah secara drastis dari pembelajaran tatap muka menjadi pembelajaran di rumah secara daring atau online. Sejak munculnya kasus pasien positif COVID 19 di Indonesia, Pemerintah melalui Kementrian Pendidikan dan Kebudayaan dan Kementrian Agama Republik Indonesia, menerapkan sistem belajar online. Dalam proses belajar, guru tidak lagi harus bertatap muka secara langsung dengan siswa karena dapat dilakukan secara online. 
Guru memiliki kontribusi yang sangat penting dalam mencetak generasi penerus bangsa. Guru juga memiliki peran utama dalam pembangunan pendidikan, khususnya yang diselenggarakan di sekolah formal. Guru sangat menentukan akan keberhasilan siswa. Guru merupakan komponen yang paling berpengaruh dalam terciptanya proses dan hasil pembelajaran yang berkualitas ${ }^{1}$.

Saat ini, salah satu solusi agar Kegiatan Belajar Mengajar dan perkuliahan tetap berjalan adalah dengan menyelenggarakan pembelajaran jarak jauh secara penuh dan memanfaatkan berbagai platform pendidikan daring. Selain itu, bisa juga dengan menerapkan sistem pembelajaran jarak jauh semi daring yaitu tugas dikirim melalui aplikasi pesan dan tidak ada interaksi langsung, dan yang tidak memiliki akses internet, listrik maupun televisi.

Pembelajaran jarak jauh sebenarnya memiliki konsep yang sama dengan pembelajaran tatap muka pada umumnya. Dimana guru berperan untuk menstimulus motivasi siswa selama proses pembelajaran berlangsung. Guru menjadi garda terdepan untuk meningkatkan motivasi siswa selama pembelajaran jarak jauh. Seorang guru dituntut untuk memiliki kemampuan menjadi inovator, motivator, fasilitator, pembimbing dan konselor dalam pengamalan pembudayaan ajaran agama di sekolah. Dengan demikian, perilaku-perilaku menyimpang peserta didik di sekolah dapat diatasi dengan penerapan budaya islami yang digagas oleh guru.

Sardiman menyatakan bahwa peranan guru adalah sebagai komunikator, sahabat yang dapat memberikan nasihat-nasihat, motivator sebagai pemberi inspirasi dan dorongan, pembimbing dalam pengembangan sikap dan tingkah laku serta nilai-nilai, dan orang yang menguasai bahan yang diajarkan ${ }^{2}$.

Secara umum, ada tiga tugas guru sebagai profesi, yakni mendidik, mengajar dan melatih. Mendidik berarti meluruskan dan mengembangkan nilai-nilai hidup, mengajar berarti meneruskan dan mengembangkan ilmu pengetahuan, melatih berarti mengembangkan keterampilan-keterampilan untuk kehidupan peserta didik. Untuk dapat melaksanakan tugas itu, seorang guru dituntut memiliki kemampuan dan kompetensi tertentu sebagai bagian dari profesiaonalisme guru.

Sehubungan dengan hal tersebut, dalam Undang-Undang Republik Indonesia Nomor 14 tahun 2015 tentang guru dan dosen menyatakan bahwa "Kompetensi guru meliputi komptenesi pedagogik, kompetensi kepribadian, kompetensi sosial, dan kompetensi profesional. Keempat kompetensi tersebut merupakan syarat yang mesti dimiliki oleh guru."3

Namun, khusus untuk guru PAI, Kementerian Agama Republik Indonesia menetapkan lima kompetensi yang harus dimiliki oleh guru pai, yaitu: kompetensi

\footnotetext{
${ }^{1}$ Mulyasa, Menjadi Guru Professional: Menciptakan Pembelajaran Kreatif dan Menyenangkan, Bandung: PT Remaja Rosdakarya, 2016, hal. 5.

${ }^{2}$ Sardiman, Interaksi\&Motivasi Belajar Mengajar, Jakarta: Rajawali Pers, 2016, hal. 143.

${ }^{3}$ Undang-Undang Dasar Republik Indonesia Nomor 14 Tahun 2005.
} 
pedagogik, kepribadian, sosial, professional dan kompetensi kepemimpinan. Kompetensi tersebut diatur dalam Peraturan Menteri Agama Republik Indonesia Nomor 16 tahun 2010 Tentang Pengelolaan Pendidikan Agama pada sekolah, bab VI pasal 6 ayat 1-6. Adapun mengenai kompetensi kepemimpinan (leadership), yaitu: "Kemampuan membuat perencanaan pembudayaan pengamalan ajaran agama pada komunitas sekolah sebagai bagian dari proses pembelajaran agama, kemampuan mengorganisasikan potensi unsur sekolah secara sistematis untuk mendukung pembudayaan pengamalan ajaran agama pada komunitas sekolah, kemampuan menjadi inovator, motivator, fasilitator, pembimbing dan konselor dalam pembudayaan pengamalan ajaran agama pada komunitas sekolah; serta kemampuan menjaga, mengendalikan dan mengarahkan pembudayaan pengamalan ajaran agama pada komunitas sekolah dan menjaga keharmonisan hubungan antar pemeluk agama dalam bingkai Negara Kesatuan Republik Indonesia."

Idealnya, pembelajaran jarak jauh dapat terkendali dan efektif dalam memunculkan motivasi belajar siswa apabila kompetensi leadership guru baik. Namun, berdasarkan observasi awal yang dilakukan oleh peneliti, masih banyak ditemukan siswa yang kurang memiliki motivasi belajar dalam pembelajaran jarak jauh ini ditandai dengan mematikan kamera pada saat proses pembelajaran daring berlangsung, telat dalam mengirim tugas yang diberikan oleh guru, bahkan absen pada saat pembelajaran daring berlangsung.

Berdasarkan latar belakang yang diuraikan diatas, maka dapat dijadikan sebagai rumusan masalah berikut; 1). Bagaimana kompetensi leadership guru PAI kelas XI Madrasah Aliyah Darul Muttaqien?, 2). Bagaimana motivasi belajar siswa kelas XI Madrasah Aliyah Darul Muttaqien dalam Pembelajaran Jarak Jauh?, 3). Apakah terdapat hubungan antara kompetensi leadership guru pai dengan motivasi belajar siswa kelas XI Madrasah Aliyah Darul Muttaqien dalam Pembelajaran Jarak Jauh?.

\section{METODE PENELITIAN}

Pendekatan yang diterapkan pada penelitian ini adalah pendekatan kuantitatif. Penelitian kuantitatif merupakan penelitian yang mengandung kaidah-kaidah ilmiah seperti konkrit/empiris, obyektif, terukur, rasional, dan sistematis. Penelitian kuantitatif merupakan penelitian yang datanya berupa angka-angka dan analisis menggunakan statistik $^{5}$. Penelitian ini menggunakan metode korelasional, penelitian ini mengkaji dua variabel. Dalam penelitian ini, yang menjadi variabel bebas (independent) adalah Kompetensi Leadership Guru PAI (Variabel X) dan yang menjadi variabel terikat (dependent) adalah Motivasi Siswa (Variabel Y).

Penelitian ini dilaksanakan di Madrasah Aliyah Darul Muttaqien yang berlokasi di Jalan Raya Parung Bogor KM 41 Jabon Mekar, Parung, Kabupaten Bogor, Jawa Barat.

\footnotetext{
${ }^{4}$ Peraturan Menteri Agama Republik Indonesia Nomor 16 Tahun 2010.

${ }^{5}$ Sugiyono, Metode Penelitian Kuantitaif, Kualitatif dan R\&D, Bandung: Alfabeta, 2017, hal. 6.
} 
Penelitian ini dilaksanankan pada bulan September 2020 dan penelitian ini dilakukan pada siswa kelas XI Madrasah Aliyah sebanyak 89 responden dari populasi 120 siswa.

Terdapat dua hal utama yang mempengaruhi kualitas data hasil penelitian, yaitu, kualitas instrumen penelitian dan kualitas pengumpulan data. Pengumpulan data dapat dilakukan dalam berbagai setting, berbagai sumber dan berbagai cara. Bila dilihat dari settingnya, data dapat dikumpulkan pada setting alamiah sedangkan bila dilihat dari sumber datanya, maka pengumpulan data dapat menggunakan sumber primer dan sumber sekunder ${ }^{6}$.

Untuk mencari dan mengumpulkan data dalam penelitian ini, peneliti menggunakan angket. Angket adalah sejumlah pernyataan yang digunakan untuk memperoleh informasi dari responden (siswa kelas XI Madrasah Aliyah Darul Muttaqien) dalam arti laporan tentang hubungan kompetensi leadership guru PAI dengan motivasi belajar yang mereka rasakan. Adapun dalam hal ini angket atau kuisioner tertutup untuk mendapatkan data data yang diinginkan oleh peneliti. Angket untuk variabel $\mathrm{X}$ tentang kemampuan leadership guru PAI diadaptasi dari angket yang dibuat oleh Rizqy Muthmainnah (2020) ${ }^{7}$ dan angket untuk variabel Y tentang motivasi belajar siswa diadaptasi dari angket milik Naa'imatul Hidayah (2019) ${ }^{8}$. Dalam penelitian ini, menyesuaikan angket dalam konsep pembelajaran jarak jauh.

Instrumen yang digunakan dalam penelitian ini adalah pengukuran variabel $\mathrm{x}$ (kompetensi leadership guru pai) dan variabel y (motivasi belajar siswa) dalam penelitian ini diukur menggunakan angket atau kuisioner.Teknik analisis data pada penelitian ini menggunakan uji normalitas dilakukan dengan uji Kolmogrov-smirnov Test dan uji korelasional menggunakan program spss 22.0 for windows.

\section{KAJIAN TEORI}

\section{Kompetensi Leadership}

\section{a. Pengertian Kompetensi Guru PAI}

Kompetensi berasal dari kata competency yang berarti kemampuan atau kecakapan. Menurut Kamus Besar Bahasa Indonesia kompetensi dapat diartikan sebagai kewenangan atau kekuasaan untuk menentukan atau memutuskan suatu hal. Pengertian dasar dari kompetensi adalah kemampuan atau kecakapan. Hambali menyebutkan beberapa makna dari istilah kompetensi yaitu ${ }^{9}$ :

\footnotetext{
${ }^{6}$ Ibid.

${ }^{7}$ Rizqy Muthmainnah Amin, Skripsi: "Pengaruh Kompetensi Leadership Guru PAI Terhadap Kecerdasan Komunikasi Interpersonal Peserta didik SMPN 1 Enrekang”, Makassar: UIN Alauddin, 2020, hal. 83

${ }^{8}$ Naaimatul Hidayah, Skripsi: "Pengaruh Persepsi Siwa Tentang Kompetensi Guru PAI Terhadap Motivasi Belajar Siswa Pada Mata Pelajaran PAI di SMA Surya Buana Kota Malang, Malang: UIN Maulana Malik Ibrahim, 2019, hal. 85.

${ }^{9}$ Muh. Hambali, "Manajemen Pengembangan Kompetensi Guru PAI". Jurnal MPI. Vol 1, 2016, hal. 72 .
} 
a. Kompetensi mengacu pada kemampuan melaksanakan sesuatu yang diperoleh melalui pendidikan.

b. Kompetensi adalah menggambarkan kualifikasi atau kemampuan seseorang, baik yang kualitatif maupun kuantitatif

c. Kompetensi merupakan suatu tugas yang memadai atas kepemilikan pengetahuan, keterampilan dan kemampuan yang dituntut oleh jabatan seseorang.

d. Kompetensi juga berarti sebagai pengetahuan, keterampilan dan nilai-nilai dasar yang direflesikan dalam kebiasaan berpikir dan bertindak.

Kompetensi guru merupakan serangkaian indikator profesionalisme guru yang berpengaruh dalam tugasnya atau dapat dikatakan juga sebagai gambaran kualitas guru dalam melaksanakan tugasnya. Kompetensi guru juga dapat diartikan sebagai serangkaian pengetahuan, skill dan sikap yang harus dikuasai guru ${ }^{10}$.

Hamalik menyebutkan ada lima kompetensi yang harus dimiliki oleh guru PAI, yaitu:

a. Kompetensi personal, artinya seorang guru harus memiliki kepribadian yang mantap yang patut untuk diteladani.

b. Kompetensi profesional, artinya seorang guru harus memiliki pengetahuan yang luas, mendalam dari bidang studi yang diajarkannya, memilih dan menggunakan berbagai metode mengajar dalam belajar mengajar yang diselenggarakannya

c. Kompetensi sosial, artinya seorang guru harus mampu berkomunikasi baik dengan siswa, sesama guru maupun masyarakat luas.

d. Kompetensi pedagogik, artinya guru memiliki kemampuan dalam memahami siswa dan suasana atau kondisi kelas.

e. Kompetensi kepemimpinan, kompetensi ini harus dimiliki oleh guru PAI. Dalam hal ini terkait dengan mempengaruhi orang lain.

Kompetensi guru PAI yakni pendidikan penting bagi kehidupan manusia, terutama dalam mencapai ketentraman batin dan kesehatan mental. Agama Islam merupakan bimbingan hidup yang paling baik, pencegah perbuatan salah yang paling ampuh, pengendali moral tiada tara. Maka, kompetensi guru PAI adalah kewenangan untuk menentukan pendidikan agama Islam yang akan diajarkan pada jenjang tertentu di sekolah tempat guru tersebut mengajar.

\section{b. Kompetensi Leadership Guru PAI}

Kompetensi merupakan kemampuan dan kewenangan guru dalam melaksanakan keguruannya. Kompetensi guru PAI merupakan suatu kemampuan dalam melaksanakan kewajiban-kewajiban secara bertanggung jawab dan layak di bidang pendidikan agama Islam, salah satunya adalah kompetensi leadership. Leadership merupakan terjemahan

\footnotetext{
${ }^{10}$ Aswatun Hasanah, "Pentingnya Kompetensi Leadership Guru MI". Indonesian Journal of Islamic Educational Management. Vol 3 No 1, April 2020, hal. 12.
} 
dari bahasa inggris yang artinya kepemimpinan. Kepemimpinan adalah sebuah pengaruh, yang berasal dari sebuah kepercayaan yang terbentuk dari sifat rahman dan rahim-Nya, integritas, bimbingan dan kepribadian. Kepemimpinan diterjemahkan dalam istilah adalah sifat-sifat, perilaku, pribadi, pengaruh terhadap orang lain, pola-pola interaksi, hubungan kerja sama antarperan dan kedudukan dari suatu jabatan.

Kata leadership pertama kali muncul tahun 1700-an. Pada tahun 1920-an, kepemimpinan didefinisikan sebagai kemampuan untuk memengaruhi pengikut agar menjadi taat, hormat, setia dan mudah bekerja sama. Definisi ini adalah definisi yang paling lama dan menjadi dasar bagi definisi kepemimpinan. Pendapat lain mengatakan bahwa kepemimpinan adalah tindakan memengaruhi orang lain untuk mencapai tujuan akhir yang diharapkan ${ }^{11}$. Nasution dalam Rahayu menyatakan bahwa kepemimpinan merupakan kemampuan untuk menggerakkan, memengaruhi, memotivasi, mengajak, mengarahkan, menasehati, membimbing, menyuruh, memerintah, melarang dan menghukum (jika perlu) serta membina dengan maksud mencapai tujuan administrasi secara efektif dan efesien ${ }^{12}$.

Kompetensi leadership guru PAI sangat berperan penting untuk meningkatkan kemampuannya sebagai pendidik. Selain itu, guru PAI juga harus menjadi teladan bagi siswa, guru-guru lain dan seluruh anggota yang ada dalam komunitas sekolah. Mampu mendorong dan mengarahkan warga sekolah agar mau mengamalkan ajaran agama Islam. Kompetensi leadership menjadi salah satu kompetensi yang penting bagi guru PAI, karena guru merupakan teladan bagi siswanya. Dengan kompetensi ini, diharapkan seorang guru merasa bahwa dirinya sebagai pemimpin dan memberikan teladan bagi siswanya. Selain itu, guru diharapkan mampu membuat perubahan kepada siswanya dari yang kurang baik menjadi baik ${ }^{13}$.

\section{c. Indikator Kompetensi Leadership Guru PAI}

Indikator kompetensi leadership sebagaimana yang dimaksud Permenag Nomor 16 tahun 2010 tentang Pengelolaan Pendidikan agama di sekolah dalam pasal 16 ayat 1 ada 4 yaitu:

1. Kemampuan dalam Perencanaan Pembudayaan Islami

2. Kemampuan dalam Mengorganisasikan Potensi Sekolah

3. Kemampuan Guru PAI untuk menjadi Inovator, Motivator, Fasilitator, Pembimbing dan Konselor.

${ }^{11}$ Husaini Usman, Kepemimpinan Efektif: Teori, Penelitian \& Praktik, Jakarta: PT Bumi Aksara, 2019, hal. 9.

${ }^{12}$ Reka Rahayu, "Pengaruh Kepemimpinan Guru Dan Keterampilan Manajemen Kelas Terhadap Perilaku Belajar Siswa Kelas IV". Jurnal Pendidikan Dasar PerKhasa. Vol. 4 No 2, Oktober 2018, hal. 223.

${ }^{13}$ M. Hanif Satria Budi, "Manajemen Pengembangan Kompetensi Kepribadian Dan Leadership Guru Pendidikan Agama Islam”. Jurnal Dirasah, Vol.1 No. 1, Februari 2018, hal. 100. 
4. Kemampuan Menjaga, Mengendalikan, dan Mengarahkan Pembudayaan Pengamalan Ajaran Agama Islam pada Komunitas Sekolah.

Guru juga bertanggungjawab dalam melaksanakan kegiatan pendidikan di sekolah, dalam arti memberikan bimbingan dan pengajaran kepada para siswa. Tanggung jawab ini direalisasikan dalam bentuk melaksanakan pembinaan kurikulum, menuntun para siswa belajar, membina pribadi, watak dan jasmani siswa, menganalisis kesulitan belajar serta menilai kemajuan belajar siswa.

Maka dari itu, dapat disimpulkan bahwa untuk meningkatkan kompetensinya, guru PAI harus rajin membaca buku referensi dan aktif mengikuti workshop dan berbagai pelatihan guru. Seorang guru juga harus memahami kondisi dan perbedaan setiap siswanya dan memahami tingkat kemampuannya dalam berbahasa dan menangkap materi yang disampaikan.

\section{d. Faktor Yang Mempengaruhi Kompetensi Leadership Guru PAI}

Guru merupakan orang yang memiliki tanggungjawab pada tumbuh kembang siswa baik pada proses pembelajaran, melakukan pembinaan dan memberi pelatihan. Kompetensi guru tidaklah sebatas kemampuan terhadap pengetahuannya saja, melainkan kemampuan guru terhadap praktik kegiatan belajar mengajar, kemampuan berkomunikasi dengan siswa serta kemampuan sebagai panutan untuk warga sekolah.

Bahrun dalam Hasanah menyebutkan beberapa faktor yang mempengaruhi kompetensi leadership guru adalah:

a. Supervisi pendidikan, yaitu melakukan pembinaan secara terus menerus yang telah dirancang untuk membantu guru dalam melakukan pekerjaan

b. Pendidikan dan pelatihan, yaitu suatu cara untuk mengembangkan mutu atau kualitas dari guru dengan proses dan metode agar tercapai hasil yang diinginkan. Pendidikan dan pelatihan dilakukan melalui intervise training dengan tujuan untuk mencapai mutu pengetahuan, pengalaman dan kecakapan guru

c. Pemberian motivasi, yaitu dilakukan untuk mendorong dan mengubah energy positif dalam meningkatkan kompetensi guru.

Warsiyah dalam Budi mengatakan bahwa kompetensi tidak dapat dimilki oleh seorang guru dengan begitu saja tanpa adanya proses pembentukan dan perolehan kompetensi yang cukup lama. Hal ini karena untuk memiliki kompetensi guru, seorang guru harus memiliki berbagai pengetahuan dan keterampilan untuk mendukung tugasnya sebagai guru. Pengetahuan dan keterampilan tersebut tidak bisa dimiliki tanpa adanya proses belajar dan latihan.

\section{Motivasi Belajar Siswa}

\section{a. Konsep Motivasi Belajar}

Belajar merupakan aktivitas sadar yang dilakukan oleh seseorang sehingga merubah pemahaman dan tingkah lakunya. Perubahan tingkah laku ini dilakukan dalam rangka memperjuangkan nilai-nilai kebaikan (virtues). Apabila proses belajar ini tidak 
diarahkan pada nilai-nilai kebaikan, maka belajar itu tidak lagi bermakna. Hal inilah yang menyebabkan proses belajar dalam hal kejahatan seperti mencuri tidak dapat dikatakan sebagai sebuah proses belajar ${ }^{14}$

Motivasi dapat diartikan sebagai aktualisasi dari daya kekuatan dalam diri individu yang dapat mengaktifkan dan mengarahkan perilaku yang merupakan perwujudan dari interaksi terpadu antara motif dan need dengan situasi yang diamati dan dapat berfungsi untuk mencapai tujuan yang diharapkan individu, yang berlangsung dalam suatu proses yang dinamis ${ }^{15}$. Motivasi adalah suatu usaha yang disadari untuk menggerakkan, mengarahkan dan menjaga tingkah laku seseorang agar ia terdorong untuk bertindak melakukan sesuatu sehingga mencapai hasil atau tujuan tertentu. Motivasi dipandang sebagai dorongan mental yang menggerakkan dan mengarahkan perilaku manusia, termasuk perilaku belajar. Dalam motivasi terkandung adanya keinginan yang mengaktifkan, menggerakkan, menyalurkan dan mengarahkan sikap serta perilaku pada individu belajar ${ }^{16}$.

Motivasi belajar adalah segala usaha di dalam diri sendiri yang menimbulkan kegiatan belajar. Motivasi belajar juga merupakan kecenderungan siswa dalam melakukan segala kegiatan belajar yang didorong oleh hasrat untuk mencapai prestasi belajar sebaik mungkin. Motivasi belajar merupakan faktor psikis yang bersifat non intelektual dan perperan dalam menumbuhkan semangat belajar untuk individu. Peran motivasi dalam proses pembelajaran, motivasi belajar siswa dapat dianalogikan sebagai bahan bakar untuk menggerakkan mesin motivasi belajar, mendorong siswa berperilaku aktif untuk berprestasi di dalam kelas. Akan tetapi, setiap siswa perlu jangka waktu untuk bisa meresapi, menghayati dan melakukan bagaimana teori motivasi tersebut bisa diterapkan didalam kehidupan sehari-hari khusuunya dalam hal pendidikan

\section{b. Macam Macam Motivasi Belajar}

Haq membahas motivasi dari dua sudut pandang, yakni motivasi yang berasal dari diri seseorang yang disebut "motivasi intrinsik" dan motivasi yang berasal dari diri seseorang yang disebut "motivasi ekstrinsik"17.

1) Motivasi Instrinsik

Motivasi instrinsik maksudnya adalah motif-motif yang menjadik aktif tanpa rangsangan dari luar, karena dalam setiap diri individu sudah ada dorongan untuk melakukan sesuatu. Disebut motivasi instrinsik bila tujuannya inhern dengan situasi belajar dan bertemu dengan kebutuhan dan tujuan siswa untuk menguasai nilai-nilai yang terkandung di dalam mata pelajaran. Sejalan dengan pendapat Hamalik dalam Ernata

\footnotetext{
${ }^{14}$ Imanuel Sairo Awang, "Strategi Pembelajaran, Tinjauan Umum Bagi Pendidik, Kalimantan: STKIP Persada Khatulistiwa, 2017, hal. 1.

${ }^{15}$ Widayat Prihartanta, "Teori-teori motivasi”, Jurnal Adabiya, Vol. 1 No. 83, hal. 10.

${ }^{16}$ Ghulam Hamdu, "Pengaruh Motivasi Belajar Siswa Terhadap Prestasi Belajar IPA Di Sekolah Dasar", Jurnal Penelitian Pendidikan, Vol.12 No.1, April 2011, hal. 83.

${ }^{17}$ Azhar Haq, “ Motivasi Belajar Dalam Meraih Prestasi”, Jurnal Vicratina, Volume 3 Nomor 1, Mei 2005, hal. 195-196.
} 
bahwa motivasi instrinsik adalah hal dan keadaan yang berasal dari dalam diri peserta didik sendiri yang dapat mendorongnya dalam melakukan tindakan belajar. Berdasarkan uraian di atas jelaslah bahwa motivasi mendorong timbulnya kelakuan dan mempengaruhi serta mengubah kelakuan ${ }^{18}$.

Motivasi itu muncul karena siswa membutuhkan sesuatu dari apa yang dipelajarinya. Motivasi memang berhubungan kebutuhan seseorang bahwa suatu objek, seseorang, suatu soal atau suatu situasi ada sangkut paut dengan dirinya. Perlu ditegaskan, bahwa siswa yang memilki motivasi instrinsik cenderung akan menjadi orang yang terdidik, yang berpengetahuan, yang mempunyai keahlian dalam bidang tertentu. Jadi, motivasi instrinsik muncul berdasarkan kesadaran dengan tujuan esensial, bukan sekedar atribut dan seremonial.

\section{2) Motivasi Ekstrinsik}

Motivasi ekstrinsik adalah motif-motif yang aktif karena ada rangsangan dari luar. Motivasi belajar dapat dikatan ekstrinsik apabila siswa menempatkan tujuan belajarnya di luar faktor-faktor situasi belajar. Siswa belajar karena hendak mencapai tujuan yang terletak diluar hal yang dipelajarinya. Misalnya, untuk mendapatkan nilai yang tinggi, gelar atau kehormatan. Motivasi ekstrinsik bukanlah motivasi yang tidak diperlukan oleh siswa dan bukan berarti tidak baik di dunia pendidikan. Motivasi ekstrinsik diperlukan agar siswa mau belajar. Motivasi ekstrinsik tidak selalu buruk akibatnya. Motivasi ekstrinsik sering digunakan karena pelajaran yang kurang menarik perhatian siswa.

Motivasi ekstrinsik dalam proses pembelajaran tetap penting. Sebab kemungkinan besar keadaan siswa itu dinamis, berubah-ubah, dan juga mungkin komponen-komponen lain dalam proses belajar mengajar ada yang kurang menarik bagi siswa, sehingga diperlukan motivasi ekstrinsik. Motivasi ekstrinsik yang positif akan berpengaruh positif dalam merangsang siswa untuk giat belajar. Motivasi ekstrinsik sangat diperlukan apabila siswa tidak memilki motivasi instrinsik di dalam dirinya sebagai seorang subjek belajar.

\section{c. Indikator Motivasi Belajar}

Hakikat motivasi belajar adalah dorongan internal dan eksternal pada siswa yang sedang belajar untuk mengadakan perubahan tingkah laku, pada umumnya dengan beberapa indikator atau unsur yang mendukung. Indikator motivasi belajar dapat diklasifikasikan sebagai berikut:

1. Dorongan mencapai seseuatu yaitu suatu kondisi dimana individu berjuang mencapai sesuatu untuk memenuhi standar yang ingin dicapai dalam belajar.

2. Komitmen salah satu aspek yang cukup penting dalam belajar. Dimana siswa yang memiliki komitmen dia akan merasa bahwa dirinya memiliki tugas, kewajiban dan tanggung jawab dalam belajar.

${ }^{18}$ Yusvidha Ernata, “Analisis Motivasi Belajar Peserta Didik Melalui Pemberian Reward Dan Punishment Di SDN Ngaringan 05 Kec. Gandusari”, Jurnal Pemikiran dan Pengembangan SD, Vol. 5 Nomor 2, September 2017, hal. 783. 
3. Inisiatif, siswa yang memiliki insiatif sudah memiliki pemikiran dan pemahaman sendiri.

4. Optimis, suatu sikap yang gigih dalam mengejar tujuan tanpa harus peduli adanya kegagalan dan kemunduran. Siswa yang memiliki sikap optimis tidak akan menyerah ketika ia belajar

\section{HASIL PENELITIAN DAN PEMBAHASAN}

Berikut ini diuraikan hasil penelitian yang telah didapatkan:

\section{Uji Normalitas}

Tabel 1 Uji Normalitas

\begin{tabular}{|c|c|c|}
\hline \multicolumn{3}{|c|}{ One-Sample Kolmogorov-Smirnov Test } \\
\hline & & Unstandardized Residual \\
\hline \multicolumn{2}{|l|}{$\mathrm{N}$} & 89 \\
\hline \multirow[t]{2}{*}{ Normal Parameters ${ }^{\mathrm{a}, \mathrm{b}}$} & Mean & .0000000 \\
\hline & Std. Deviation & 3.64008305 \\
\hline \multirow[t]{3}{*}{ Most Extreme Differences } & Absolute & 0.163 \\
\hline & Positive & 0.163 \\
\hline & Negative & -0.094 \\
\hline \multicolumn{2}{|l|}{ Test Statistic } & .163 \\
\hline \multicolumn{2}{|l|}{ Asymp. Sig. (2-tailed) } & $.200^{\mathrm{c}, \mathrm{d}}$ \\
\hline
\end{tabular}

a. Test distribution is Normal.

b. Calculated from data.

c. Lilliefors Significance Correction.

d. This is a lower bound of the true significance.

Dari Tabel diatas menunjukan nilai tes kolmogorov-smirnov dengan nilai signifikan 0,200 lebih besar dari 0,05, sehingga dapat disimpulkan data yang digunakan berdistribusi normal.

\section{Deskripsi Data Kompetensi Leadership Guru PAI di Kelas XI MA Darul} Muttaqien

Untuk mengetahui hubungan kemampuan leadership guru pai dengan motivasi belajar siswa dalam pembelajaran jarak jauh di MA Darul Muttaqien, peneliti 
menggunakan data yang diperoleh dari hasil penyebaran angket yaitu, dengan menyebarkan secara langsung kepada siswa kelas XI MA Darul Muttaqien agar menghasilkan data yang relevan. Berikut adalah tabel deskripsi data kompetensi leadership guru PAI di kelas XI MA Darul Muttaqien:

Tabel 2 Deskripsi Data Kompetensi Leadership Guru PAI di Kelas XI MA Darul Muttaqien

\begin{tabular}{|c|c|c|c|c|c|c|c|c|c|c|c|}
\hline \multirow{2}{*}{ No } & \multirow{2}{*}{ Pernyataan } & \multicolumn{2}{|c|}{$\begin{array}{c}\text { Tidak } \\
\text { Pernah }\end{array}$} & \multicolumn{2}{|c|}{$\begin{array}{l}\text { Kadang- } \\
\text { Kadang }\end{array}$} & \multicolumn{2}{|c|}{ Jarang } & \multicolumn{2}{|c|}{ Sering } & \multicolumn{2}{|c|}{ Selalu } \\
\hline & & $\mathbf{F}$ & $\%$ & $\mathbf{F}$ & $\%$ & $\mathbf{F}$ & $\%$ & $\mathbf{F}$ & $\%$ & $\mathbf{F}$ & $\%$ \\
\hline 1 & $\begin{array}{l}\text { Guru memberi salam } \\
\text { sebelum memulai } \\
\text { pembelajaran online }\end{array}$ & 0 & $0 \%$ & 0 & $0 \%$ & 0 & $0 \%$ & 18 & $20 \%$ & 71 & $80 \%$ \\
\hline 2 & $\begin{array}{lr}\text { Guru membiasakan } \\
\text { berdo'a sebelum } \\
\text { memulai pelajaran }\end{array}$ & 0 & $0 \%$ & 0 & $0 \%$ & 6 & $7 \%$ & 21 & $22 \%$ & 63 & $71 \%$ \\
\hline 3 & $\begin{array}{l}\text { Guru menunda } \\
\text { sejenak pembelajaran } \\
\text { online ketika adzan } \\
\text { berkumandang }\end{array}$ & 0 & $0 \%$ & 0 & $0 \%$ & 9 & $10 \%$ & 12 & $14 \%$ & 68 & $76 \%$ \\
\hline 4 & $\begin{array}{ll}\text { Guru } & \text { memberi } \\
\text { motivasi } & \text { sebelum } \\
\text { memulai pelajaran }\end{array}$ & 0 & $0 \%$ & 3 & $3 \%$ & 12 & $14 \%$ & 41 & $46 \%$ & 33 & $37 \%$ \\
\hline 5 & $\begin{array}{l}\text { Guru memberi nasihat } \\
\text { kepada siswa }\end{array}$ & 0 & $0 \%$ & 3 & $3 \%$ & 21 & $23 \%$ & 27 & $30 \%$ & 39 & $44 \%$ \\
\hline 6 & $\begin{array}{l}\text { Guru menegur siswa } \\
\text { ketika tidak mengikuti } \\
\text { pembelajaran online }\end{array}$ & 0 & $0 \%$ & 6 & $7 \%$ & 6 & $7 \%$ & 24 & $26 \%$ & 53 & $60 \%$ \\
\hline 7 & $\begin{array}{l}\text { Guru menegur siswa } \\
\text { yang tidak fokus } \\
\text { ketika pembelajaran } \\
\text { online berlangsung }\end{array}$ & 0 & $0 \%$ & 3 & $4 \%$ & 18 & $20 \%$ & 35 & $39 \%$ & 33 & $37 \%$ \\
\hline 8 & $\begin{array}{l}\text { Guru bertutur kata } \\
\text { dengan baik }\end{array}$ & 0 & $0 \%$ & 0 & $0 \%$ & 3 & $3 \%$ & 27 & $30 \%$ & 59 & $67 \%$ \\
\hline 9 & $\begin{array}{l}\text { Guru membawakan } \\
\text { materi dengan baik }\end{array}$ & 0 & $0 \%$ & 0 & $0 \%$ & 27 & $30 \%$ & 26 & $30 \%$ & 36 & $40 \%$ \\
\hline 10 & $\begin{array}{l}\text { Guru mengingtakan } \\
\text { siswa untuk sholat } \\
\text { lima waktu }\end{array}$ & 0 & $0 \%$ & 3 & $3 \%$ & 20 & $23 \%$ & 34 & $33 \%$ & 31 & $40 \%$ \\
\hline & TOTAL & 89 & $100 \%$ & 89 & $100 \%$ & 89 & $100 \%$ & 89 & $100 \%$ & 89 & $100 \%$ \\
\hline
\end{tabular}

\section{Deskripsi Data Motivasi Belajar Siswa Dalam Pembelajaran Jarak Jauh di Kelas XI MA Darul Muttaqien}

Untuk mengetahui hubungan kemampuan leadership guru pai dengan motivasi belajar siswa dalam pembelajaran jarak jauh di MA Darul Muttaqien, peneliti menggunakan data yang diperoleh dari hasil penyebaran angket yaitu, dengan menyebarkan secara langsung kepada siswa kelas XI MA Darul Muttaqien agar 
menghasilkan data yang relevan. Berikut adalah tabel deskripsi data kompetensi motivasi belajar siswa di kelas XI MA Darul Muttaqien dalam pembelajaran jarak jauh:

Tabel 3. Deskripsi Data Motivasi Belajar Siswa Kelas XI MA Darul Muttaqien dalam Pembelajaran Jarak Jauh

\begin{tabular}{|c|c|c|c|c|c|c|c|c|c|c|c|}
\hline \multirow{2}{*}{ No } & \multirow[t]{2}{*}{ Pernyataan } & \multicolumn{2}{|c|}{$\begin{array}{c}\text { Tidak } \\
\text { Pernah } \\
\end{array}$} & \multicolumn{2}{|c|}{$\begin{array}{l}\text { Kadang- } \\
\text { Kadang }\end{array}$} & \multicolumn{2}{|c|}{ Jarang } & \multicolumn{2}{|c|}{ Sering } & \multicolumn{2}{|c|}{ Selalu } \\
\hline & & $\mathbf{F}$ & $\%$ & $\mathbf{F}$ & $\%$ & $\mathbf{F}$ & $\%$ & $\mathbf{F}$ & $\%$ & $\mathbf{F}$ & $\%$ \\
\hline 1 & $\begin{array}{lr}\text { Bertanya } & \text { kepada guru } \\
\text { ketika } & \text { mengalami } \\
\text { kesulitan } & \text { dalam } \\
\text { pembelajaran online }\end{array}$ & 3 & $3 \%$ & 12 & $13 \%$ & 12 & $13 \%$ & 30 & $34 \%$ & 32 & $37 \%$ \\
\hline 2 & $\begin{array}{l}\text { Belajar walaupun } \\
\text { tidak ada ujian }\end{array}$ & 0 & $0 \%$ & 15 & $17 \%$ & 30 & $34 \%$ & 21 & $24 \%$ & 23 & $25 \%$ \\
\hline 3 & $\begin{array}{|lr|}\text { Masuk } & \text { kelas online } \\
\text { karena } & \text { keinginan } \\
\text { sendiri } & \end{array}$ & 3 & $3 \%$ & 6 & $7 \%$ & 6 & $7 \%$ & 18 & $20 \%$ & 56 & $63 \%$ \\
\hline 4 & \begin{tabular}{|lr} 
Mencatat & hal-hal \\
penting & mengenai \\
materi & ketika \\
pembelajaran & online \\
berlangsung & \\
\end{tabular} & 0 & $0 \%$ & 3 & $3 \%$ & 6 & $7 \%$ & 32 & $36 \%$ & 48 & $64 \%$ \\
\hline 5 & $\begin{array}{ll}\text { Membaca } & \text { buku } \\
\text { pelajaran } & \end{array}$ & 0 & $0 \%$ & 3 & $3 \%$ & 14 & $16 \%$ & 26 & $29 \%$ & 46 & $52 \%$ \\
\hline 6 & $\begin{array}{ll}\text { Mencari } & \text { sumber } \\
\text { referensi lain } & \text { untuk } \\
\text { menyempurnakan } \\
\text { tugas }\end{array}$ & 0 & $0 \%$ & 0 & $0 \%$ & 12 & $13 \%$ & 54 & $61 \%$ & 23 & $26 \%$ \\
\hline 7 & $\begin{array}{|ll|}\begin{array}{l}\text { Aktif } \\
\text { berdiskusi }\end{array} & \text { dalam } \\
\end{array}$ & 3 & $3 \%$ & 9 & $10 \%$ & 18 & $20 \%$ & 24 & $27 \%$ & 35 & $40 \%$ \\
\hline 8 & $\begin{array}{lr}\text { Senang } & \text { ketika } \\
\text { pendapatnya diterima }\end{array}$ & 0 & $0 \%$ & 3 & $3 \%$ & 3 & $3 \%$ & 18 & $20 \%$ & 65 & $73 \%$ \\
\hline 9 & $\begin{array}{l}\text { Memiliki keyakinan } \\
\text { mendapat nilai bagus }\end{array}$ & 0 & $0 \%$ & 0 & $0 \%$ & 27 & $30 \%$ & 26 & $30 \%$ & 36 & $40 \%$ \\
\hline 10 & $\begin{array}{l}\text { Tidak pernah telat } \\
\text { mengumpulkan } \\
\text { dari guru }\end{array}$ & 0 & $0 \%$ & 3 & $3 \%$ & 20 & $23 \%$ & 34 & $33 \%$ & 31 & $40 \%$ \\
\hline 11 & \begin{tabular}{|l|}
$\begin{array}{l}\text { Selalu mengerjakan } \\
\text { tugas yang diberikan } \\
\text { guru }\end{array}$ \\
\end{tabular} & 0 & $0 \%$ & 3 & $3 \%$ & 9 & $10 \%$ & 24 & $27 \%$ & 53 & $60 \%$ \\
\hline 12 & \begin{tabular}{|l|} 
Selalu hadir dalam \\
mengikuti \\
pembelajaran online
\end{tabular} & 33 & $37 \%$ & 0 & $0 \%$ & 21 & $33 \%$ & 12 & $13 \%$ & 41 & $47 \%$ \\
\hline 13 & $\begin{array}{l}\text { Memperhatikan guru } \\
\text { ketika pembelajaran } \\
\text { online }\end{array}$ & 9 & $10 \%$ & 0 & $0 \%$ & 6 & $7 \%$ & 18 & $20 \%$ & 56 & $63 \%$ \\
\hline
\end{tabular}




\begin{tabular}{|c|c|c|c|c|c|c|c|c|c|c|c|}
\hline 14 & $\begin{array}{l}\text { Tidak pernah ragu } \\
\text { dalam menjawab } \\
\text { pertanyaan dari guru }\end{array}$ & 6 & $7 \%$ & 12 & $13 \%$ & 15 & $17 \%$ & 24 & $27 \%$ & 32 & $37 \%$ \\
\hline TOTAL & $\mathbf{8 9}$ & $\mathbf{1 0 0 \%}$ & $\mathbf{8 9}$ & $\mathbf{1 0 0 \%}$ & $\mathbf{8 9}$ & $\mathbf{1 0 0 \%}$ & $\mathbf{8 9}$ & $\mathbf{1 0 0 \%}$ & $\mathbf{8 9}$ & $\mathbf{1 0 0 \%}$ \\
\hline
\end{tabular}

\section{Korelasi Antara Kompetensi Leadership Guru PAI dan Motivasi Belajar Siswa dalam Pembelajaran Jarak Jauh.}

Untuk mengetahui korelasi antara kompetensi leadership guru PAI dan motivasi belajar siswa di kelas XI MA Darul Muttaqien, peneliti menguji korelasi antar dua variabel tersebut menggunakan spss. Hasil uji korelasi terdapat pada tabel berikut ini:

Tabel 4. Uji Korelasi antara Kompetensi Leadership Guru PAI dan Motivasi Belajar Siswa di Kelas XI MA Darul Muttaqien

\begin{tabular}{|c|c|c|c|}
\hline \multicolumn{4}{|c|}{ Correlations } \\
\hline & & LEADERSHIP & MOTIVASI \\
\hline \multirow[t]{3}{*}{ LEADERSHIP } & Pearson Correlation & 1 & $.859^{*}$ \\
\hline & Sig. (2-tailed) & & .000 \\
\hline & $\mathrm{N}$ & 89 & 89 \\
\hline \multirow[t]{3}{*}{ MOTIVASI } & Pearson Correlation & $.859^{*}$ & 1 \\
\hline & Sig. (2-tailed) & .000 & \\
\hline & $\mathrm{N}$ & 89 & 89 \\
\hline
\end{tabular}

Tabel 5. Skala Interval

\begin{tabular}{|c|c|}
\hline Besarnya Nilai & Interprestasi \\
\hline $0,00-0,20$ & Tidak \\
\hline $0,20-0,40$ & Kurang \\
\hline $0,40-0,70$ & Sedang \\
\hline $0,70-0,90$ & Kuat \\
\hline $0,90-1,00$ & Sangat kuat \\
\hline
\end{tabular}

Setelah dilakukan uji korelasi dengan rumus korelasi pearson dengan taraf signifikan 5\%, diketahui bahwa nilai korelasi antara kompetensi leadership guru PAI dan motivasi belajar siswa di kelas XI MA Darul Muttaqien sebesar 0,859. Apabila dilihat dari tabel interpretasi nilai yang diperoleh yaitu 0,859 yang terletak antara interval 0,70 0,90 bahwa terdapat hubungan antara kemampuan leadership guru PAI dengan motivasi 
belajar siswa dalam pembelajaran jarak jauh di kelas XI MA Darul Muttaqien, dan korelasi disini bersifat kuat.

\section{SIMPULAN}

\section{A. Kesimpulan}

Berdasarkan hasil penelitian mengenai kemampuan leadership guru PAI dengan motivasi belajar siswa kelas XI MA Darul Muttaqien dalam pembelajaran jarak jauhdapat disimpulkan sebagai berikut:

1. Kompetensi leadership guru PAI di kelas XI MA Darul Muttaqien dapat dikatakan baik. Hal ini bisa dilihat melalui tabel deskripsi data kompetensi leadership guru PAI di kelas XI MA Darul Muttaqien bahwa guru selalu memberi salam sebelum masuk ke dalam kelas online, guru membiasakan berdoa sebelum memulai pembelajaran, guru selalu menunda sejenak pembelajaran disaat adzan berkumandang, guru selalu memberi motivasi sebelum memulai pelajaran, guru selalu memberi nasihat kepada siswa, guru selalu menegur siswa yang tidak ikut kelas online, guru bertutur kata dengan baik, dan guru selalu mengingatkan siswa untuk shalat lima waktu.

2. Kompetensi motivasi belajar siswa di kelas XI MA Darul Muttaqien dapat dikatakan baik. Hal ini bisa dilihat melalui tabel deskripsi data motivasi belajar siswa di kelas XI MA Darul Muttaqien bahwa mayoritas siswa kelas XI MA Darul Muttaqien selalu bertanya kepada guru jika mengalami kesulitan dalam pembelajaran online, selalu belajar walaupun tidak ada ujian, masuk kelas karena kesadaran diri, selalu membaca buku pelajaran, selalu mencatat hal-hal penting ketika pembelajaran online berlangsung, mencari sumber referensi lain untuk menyempurnakan tugas dari guru, aktif dalam berdiskusi, selalu mengerjakan tugas dari guru, tidak pernah telat dalam mengumpulkan tugas, memperhatikan guru ketika guru sedang menjelaskan dan selalu ikut kelas online.

3. Berdasarkan hasil uji korelasi dengan rumus korelasi pearson dengan taraf signifikan 5\%, diketahui bahwa nilai korelasi antara kompetensi leadership guru PAI dan motivasi belajar siswa di kelas XI MA Darul Muttaqien sebesar 0,859. Apabila dilihat dari tabel interpretasi nilai yang diperoleh yaitu 0,859 yang terletak antara interval 0,70-0,90 bahwa terdapat hubungan antara kemampuan leadership guru PAI dengan motivasi belajar siswa dalam pembelajaran jarak jauh di kelas XI MA Darul Muttaqien, dan korelasi disini bersifat kuat.

\section{B. Saran}

1. Bagi Guru

Guru merupakan pioneer utama dalam setiap proses pembelajaran baik secara tatap muka ataupun jarak jauh. Hal inilah yang menjadikan guru dituntut agar memiliki kompetensi leadership dalam memandu kegiatan belajar mengajar. Kemampuan leadership sangat harus dimiliki oleh guru untuk menegur dan mengawasi siswa pada saat proses pembelajaran tatap muka berlangsung. 


\section{Bagi Siswa}

Siswa belum mencapai tingkat maksimal dalam memotivasi dirinya sendiri dalam belajar selama proses pembelajaran jarak jauh. Hal ini merupakan salah satu alasan dari kurang efektifnya proses pembelajaran jarak jauh. Agar proses pembelajaran jarak jauh berjalan dengan efektif, maka siswa perlu meningkatkan motivasi belajar dari dalam dirinya.

\section{DAFTAR PUSTAKA}

Hambali, Muh. (2016). Manajemen Pengembangan Kompetensi Guru PAI. Jurnal MPI. Vol. 1.

Hamdu, Ghulam. (2011). Pengaruh Motivasi Belajar Siswa Terhadap Prestasi Belajar IPA Di Sekolah Dasar. Jurnal Penelitian Pendidikan. Vol. 12 No. 1.

Hasanah, Aswatun. (2020). Pentingnya Kompetensi Leadership Pada Guru MI. Indonesian Journal of Islamic Educational Management. Vol. 3 No. 1.

Haq, Azhar. (2005). Motivasi Belajar Dalam Meraih Prestasi. Jurnal Vicratina. Vol. 3 No. 1.

Hidayah, Naa'imatul. (2019). Pengaruh Persepsi siswa Tentsng Kompetensi Guru PAI Terhadap Motivasi Belajar Siswa Pada Mata Pelajaran PAI Di SMA Surya Buana Kota Malang. Malang: Universitas Islam Negeri Maulana Malik Ibrahim.

Husein, Latifah. (2017). Profesi Keguruan Menjadi Guru Profesional. Yogyakarta: Pustaka Baru Press.

Mulyasa. (2016). Menjadi Guru Profesional: Menciptakan Pembelajaran Kreatif dan Menyenangkan. Bandung: PT Remaja Rosdakarya.

Muttmainnah, Rizqy. (2020). Pengaruh Kompetensi Leadership Guru Pendidikan Agama Islam Terhadap Kecerdasan Komunikasi Interpersonal Peserta Didik SMPN 1 Enrekang. Makassar: UIN alaudin Makassar.

Perarturan Menteri Agama Republik Indonesia Nomor 16 Tahun 2010.

Prihartanta, Widayat. (2015). Jurnal Adabiya. Vol. 1 No. 83.

Rahayu, Reka. (2018). Pengaruh Kepemimpinan Guru Dan Keterampilan Manajemen Kelas Terhadap Perilaku Belajar Siswa. Jurnal Pendidikan Dasar PerKhasa. Vol. 4 No. 2. 
Usman, Husaini. (2019). Kepemimpinan Efektif: Teori, Penelitian dan Praktik. Jakarta: PT Bumi Aksara.

Sairo, Awang. (2017). Strategi Pembelajaran, Tinjauan Umum Bagi Pendidik. Kalimantan: STKIP Persada Khatulistiwa.

Satria, Hanif. (2018). Manajemen Pengembangan Kompetensi Kepribadian Dan Leadership Guru Pendidikan Agama Islam. Jurnal Dirasah. Vol. 1 No. 1. 